\title{
The International Collections of The University of Iowa Libraries
}

\author{
JOHN BRUCE HOWE L L
}

Ever since the inception of The University of Iowa, the faculty has been engaged in teaching and research on international subjects. However, since the middle of the twentieth century, international topics have begun to multiply in the curriculum. With this expansion of interest in the rest of the world, the University Libraries have started to acquire research materials to support this teaching and research.

As early as 1857 University President Amos Dean had acquired 479 titles for a library. Two of the books were Egypt, Ethiopia, and the Peninsula of Sinai, in the Years 1842-1845, During the Mission Sent Out by His Majesty Frederick William IV of Prussia, 2nd ed. (London: 1853), by Richard Lepsius (one of the founders of comparative linguistics); and Brazil and the Brazilians: Portrayed in Historical and Descriptive Sketches (Boston: 18..?) by James Fletcher. The first title is still available in the library, while the latter is no longer there, perhaps a casualty of the fire of 1897 in North Hall when 24,472 out of 33,601 library books were destroyed. Interestingly, during World War II, it was the Brazilian government's Department of Education and Health that donated a "collection of Brazilian books 'as a gesture of cultural cooperation." "1 In the post World War II era, America emerged as a superpower, and a growing interest in international studies was reflected in the University's curriculum.

In 1954 the library acquired the Human Relations Area Files (HRAF), a massive set of metal file cabinets filled with unbound books and journal articles indexed for anthropological, social,

1 Mildred Throne, "The History of the State University of Iowa: The University Libraries." (Unpublished M.A. thesis, The University of Iowa, 1943), p. 88. 
and cross-cultural studies, but also of use to historians and political scientists. Similar or identical cultural traits are located by a set of numbers that cut across all of the ethnic groups listed, permitting a comparison of the same word, for example dowry, through the whole file. Issued from Yale University, the HRAF is located in a special room on the Main Library's third floor. As the files continue to age, they will see greater use because of their historical content.

That same year, 1954, an Oriental Studies program appeared with three courses in Chinese language, two in Chinese culture, and a course on Japan in the twentieth century. By the next year, 1955, a cluster of courses appeared under the rubric Near Eastern Studies with two courses on Islam and two on the Arabic language. Arabic did not stay long in the curriculum, but Hebrew, taught in the School of Religion as Readings in Rabbinic Hebrew, still is available. In 1961 the Program of Chinese and Oriental Studies and Chinese Language and Area Center were realized with the support of the National Defense Education Act. The grant funded an undergraduate major in Chinese, scholarships, and a cross listing of 14 courses from other departments complementing the 22 courses already on the grant. Among the former were courses on all aspects of Chinese language and literature, including civilization and philosophy, with additional courses on the culture of India, Japan, Korea, and Pakistan. Among the latter were courses on the history of the Far East, Japan, and China. Also in 1961, a program in Foreign Studies was created "to familiarize the student with the geography, history, political structure, and cultural traditions of a foreign country and to train him in the practical use of its language. The following five areas and their respective languages are studied: France, Latin America, Germany and Austria, Russia, China."2

In 1966 the Chinese Language and Area Center became the Center for Far Eastern Studies. Some 62 courses were taught including an extensive program in Japanese with 18 cross-listed courses from the departments of Anthropology, History, Political Science, and Sociology as well as the schools of Art and

${ }^{2}$ The University of Iowa General Catalog, 1961, p. 97. 
Art History and Religion. The program leading to the M.A. in Chinese language and civilization, established in 1965, was followed in 1965-66 with an undergraduate major in Japanese language and civilization.

The University of Iowa Libraries' Oriental Collection was started in the early 1960s, the same time that the Chinese Language and Area Center was created. By 1966, there were "25,000 fascicules in 17,500 volumes" costing $\$ 40,000$ with the budget at roughly $\$ 10,000$ per year. Smaller numbers of titles in Japanese and Korean also were added, but "the bulk of the collection consists of basic Chinese material on history, literature, philosophy, and art." Many large sets, such as Twenty-five Dynastic Histories, also have been acquired. "It is the aim of the collection to become an adequate Chinese library for general basic reference, with special collections built around the needs of the faculty and graduate students." 3 The books and journals in the Oriental Collection are shelved separately on the third floor in the Main Library according to the language of the text.

By 1974 the Program of Chinese and Oriental Studies became the Department of East Asian Languages and Literatures, offering majors for both an M.A. and the Ph.D. Fifty-one courses on China and Japan were offered with 55 cross listed from the departments of Anthropology, History, and Political Science and the schools of Art and Art History, and Religion. Also at this time the Department of History was offering courses on Latin America, the British Empire and Commonwealth, China, Mexico, India, East Asia, and Japan. The Oriental Collection had grown to 31,531 volumes in Chinese and more than 5,000 in Japanese, being particularly strong in literature, history, art, and philosophy.

The Global Studies Program was established in 1980 "to provide undergraduate students multidisciplinary study of major contemporary, interrelated global problems concerned with war, peace, and security; development; environmental concerns and global resources; and cross-cultural understanding. ${ }^{\prime 4}$ A new course on Africa appeared in the Department of

${ }^{3}$ The University of Iowa General Catalog, 1966, p. 116.

${ }^{4}$ The University of Iowa General Catalog, 1980-82, p. 121. 
History. The Latin American Studies Program was fully established with a diverse but integrated collection of courses on ethnology, the major states of the region, Brazilian literature, the contemporary Latin American novel, sociology of the Third World, natural resources in the world economy, and Black literature of Portuguese expression. Biblical Aramaic was taught with rabbinic Hebrew in the School of Religion.

The Center for Development Studies was created in 1974 with support from the U.S. Office of Education. By the end of the 1970s, programs granting certificates were established in global studies, Latin American studies, and Asian studies, with an M.A. program in development support communications in the School of Journalism and Mass Communication in 1982. In July 1981 the Council on International and Comparative Studies, now the Center for International and Comparative Studies (CICS, pronounced kicks), came into existence. In the mid1970s a small number of younger faculty who had come to The University of lowa found an academic atmosphere lacking for interdisciplinary programs. More precisely, "the Council was established in response to a proposal presented by the chairs of the Global Studies Program, the Latin American Studies Program, and the Program in Asian Civilizations." ${ }^{15}$ Initially, the council was a committee, set up as an independent entity with U.S. Department of Education funding. In 1985 the center was upgraded to a national resource center providing new faculty and staff positions, including the position of international studies bibliographer within the University Libraries. The Center for International and Comparative Studies moved to new quarters in the newly refurbished International Center, formerly the home of the law school, in 1987. The International Center is home for the following programs: African Studies Program, Global Studies Program, Health and Development in Agrarian Societies (HADAS), Latin American Studies Program (LASP), Project for International Communications Studies (PICS), Program for International Development (PID), Program in Asian Civilization, Women in International Development

5 The University of Iowa Council on International and Cooperative Studies Annual Report, 1982-83, p. 3. 
Committee (WID), and the Center for Asian and Pacific Studies (CAPS). It must be added that from its inception, CICS has had the generous support of the Stanley Foundation, the StanleyUI Foundation, the E \& M Charities, and the Stanley family of Muscatine, Iowa.

The international studies bibliographer has many roles within the libraries: (1) to provide access to the collections already on the campus, (2) to evaluate the collections to determine future research needs, (3) to provide access to other academic libraries in Iowa, (4) to reveal the holdings of research libraries in the Midwest and throughout the United States through personal contact with colleagues as well as providing descriptive contents of those libraries, (5) to request the purchase of books and journals on research topics of interest to The University of Iowa faculty, and (6) to cooperate with members of the Research Libraries Group, Stanford, California, in a national online catalog of books and journals received by member libraries such as Yale, Columbia, and the New York Public. The international studies bibliographer also works closely with the Government Publications Department in the Main Library to acquire up-to-date statistical publications, economic development plans, and census materials; these are often the most important documents that faculty or students need to see when choosing a research topic about a particular Third World country. The University of Iowa maintains some 40 active agreements with other universities in China, Denmark, Burkina Faso, South Korea, the Federal Republic of Germany, Iceland, Indonesia, Mexico, Venezuela, Poland, France, the Netherlands, Australia, Israel, Egypt, and the United Kingdom, in the following departments and colleges: Education, Engineering, Law, Dentistry, Medicine, Pharmacy, English, French, Journalism and Mass Communication, and Urban and Regional Planning as well as the Institute of Hydraulic Research.

In order to provide better access to the literature of developing countries, the international studies bibliographer compiled Third World/Iowa: Books, Journals, Maps, and Microforms about 138 Developing Countries Acquired by The University of Iowa Libraries 1980-1986 (Iowa City: The University of Iowa Libraries, 1987. 
6 volumes). These volumes enable students and faculty on the campus to see the most recent titles that have been cataloged and are on the shelves. The 40,000 records of books and journals in all languages are arranged into six volumes: (1) Africa, (2) Asia (general) and East Asia, (3) South Asia, (4) Southeast Asia and Oceania (i.e., the Pacific countries), (5) Middle East, and (6) Latin America, and indexed by author, title, and geographic area. Each item includes the location within The University of Iowa Libraries system. Gratis sets are located at Iowa State University and the University of Northern Iowa, with other academic libraries in lowa accounting for half of the 20 copies printed. Other copies have been purchased by academic libraries in Nebraska, Missouri, New York, California, and Florida; copies in libraries abroad are in Korea, France, and the United Kingdom.

The international studies bibliographer is guided by the assistant University librarian for collection development and works with the media bibliographer and the history and social sciences bibliographer. The other necessary participants in the acquisition of international materials are the "selectors," librarians who aid in the selection of books and journals for the libraries' collections on topics such as religion, sociology, anthropology, and so forth. Some selectors are language specialists. For example, there is a selector for the humanistic studies of East and South Asia for materials in most of the indigenous languages of the region. Still another selector chooses social science materials for China, Korea, and Japan. Acquisition and access to Oriental materials have been extensively broadened in recent years. A Research Libraries Group CJK (Chinese, Japanese, Korean) computer terminal in the Cataloging Department is used to catalog new titles in the three Asian languages and also provides additional U.S. locations for titles that the libraries do not have, but may borrow from the Research Libraries Group. Finally, there is a selector for Latin America who selects publications in English and Spanish on the history of Latin America, including the Caribbean.

The Center for International and Comparative Studies (CICS) has a number of committees, including a Committee on African Studies and a Subcommittee on Publishing. The latter subcom- 
mittee is engaged in publishing three guides to rural health, one each for India, Indonesia, and Kenya, primarily because of faculty interest in applying for and obtaining foundation grants for medical research. Interest in Kenya as a place for research and scholarly activities goes back some years. The faculty has conducted studies on pesticide poisoning of the environment, the role of women in the rural setting, comparative political conditions in Kenya and its southern neighbor Tanzania, and most recently, rural health in Meru District, which is just north of Mount Kenya. Kenya has the fastest growing population in the world (now 20 million) on a limited amount of arable land. The society is an open one where democratic values are prized. The faculty and administration of The University of Iowa have been in close contact with members of the Kenya Medical Research Institute in applying for a grant that would provide exact figures on rural health problems in Kenya. As part of the grant application, a comprehensive guide to the literature on rural health in Kenya was created, not only from books and journals in the libraries, but also from citations found in large online databases. It is hoped that this guide will soon be published as the first number of a new series: Iowa International Guides. Plans are also being made to create a parallel series, Iowa International Papers, which will include important findings of faculty research about other countries.

Among the libraries' strengths in the past were holdings of history, geography, and anthropology. Considerably less funding was available for the problems and development of Third World countries: their economic welfare, rural health, communications and transportation systems, use of natural resources, and political systems. Indonesia is a good example of a country whose history has been adequately covered in the libraries' collections. Although the history of Indonesia includes extensive sets of volumes in Dutch and English, there are few titles on the social and economic problems enumerated above. Indonesia is very important both regionally in Asia and globally in its production of oil. It has more than 160 million people, making it the largest Islamic country in the world. The University of Iowa has close relations with a number of universities 
there and it is hoped that closer ties might be established in areas of mutual benefit.

Books on China and India make up 92 percent of the entire holdings of the libraries on Asia, including the Middle East. Mexico, Argentina, Brazil, Colombia, and Peru combine for 70 percent of all volumes on Latin America and the Caribbean. On the African continent, 50 percent of all titles are about Egypt, South Africa, Nigeria, and Algeria; the remaining 50 percent is shared by the other 45 African states.

Our country continues to exert considerable influence over other countries and is itself shaped by events such as economic well-being, financial stability, war and peace, terrorism, oppression, famine, and refugees. All of the problems of our day depend on how the rest of the world sees us and, equally important, how we see the people who comprise three-quarters of the earth's population. The international collections in the libraries continue to be built for use by students and faculty, in the hope that some of the solutions will come from lowa. 